\section{Chlorogavilea 'Máxima', the First Intergeneric Hybrid of Chilean Orchid}

Gabriela Verdugo Ramírez ${ }^{1}$

Facultad de Agronomía y de los Alimentos, Pontificia Universidad Católica de Valparaíso, Casilla 4-D, Quillota, Chile

Mauricio Cisternas Baez

Jardín Botánico Nacional, Casilla 488, Viña del Mar, Chile

\section{Ursula Steinfort}

Facultad de Agronomía y de los Alimentos, Pontificia Universidad Católica de Valparaíso, Casilla 4-D, Quillota, Chile

\section{Hermine Vogel}

Facultad de Agronomía, Universidad de Talca, Casilla 747, Talca, Chile

\section{Rosa Cueto-Ewoldt}

Facultad de Agronomía y de los Alimentos, Pontificia Universidad Católica de Valparaíso, Casilla 4-D, Quillota, Chile

Additional index words. terrestrial orchid, Orchidaceae, pot plants, ornamental plant breeding, Chile

The biogeographical position of Chile has allowed the development of a large number of endemic species, particularly geophytes, with great potential for the ornamental plant and cut flower industry (Bridgen et al., 2002). Chilean cut flowers and bulbs exported during 2014 and 2013 were valued at U.S. \$5.64 and \$34.5 million, respectively (ODEPA, 2015). The bulb market in particular (i.e., Zantesdechia sp., Lilium sp., and Tulipa sp.) is growing in importance, although much of the production is consumed domestically. Orchids have become one of the largest commodities in the international cut flower and ornamental plant market, with an international trade value of U.S. \$504 million in 2012, in which the genera Cymbidium, Dendrobium, and Phalaenopsis were the most traded (De and Medhi, 2015).

The first orchid hybrid was obtained in 1853 by John Dominy and since then, thousands of hybrids have been developed (Higgins and Alrich, 2013). In Chile, the Orchidaceae family is composed of seven genera, in which Chloraea Lindl. and Gavilea Poepp., are the most represented in terms of species richness (Novoa et al., 2006). Most of the species are rare, insufficiently known and endangered, because of human activities, which have dramatically reduced their ranges of distribution (Novoa et al., 2006). Both

Received for publication 24 June 2015. Accepted for publication 30 Sept. 2015.

This work was supported by Fundación para la Innovación Agraria (FIA).

We thank Enrique Matthei and all members of FIA-Chloraea project.

${ }^{1}$ Corresponding author. E-mail: gabriela.verdugo@, ucv.cl.
Chloraea and Gavilea have distinctive floral traits such as floral display, flower size, and shape within the Cranichideae tribe (Cisternas et al., 2012). Their flower characteristics with a long stem and extended vase life, suggest that these plants have great potential as a novel alternative for the cut flower market as well as a pot plant for the ornamental plant industry (Steinfort et al., 2012).

During the last decade in Chile, the Fundación para la Innovación Agraria of the Ministry of Agriculture supported several Chilean orchid breeding projects, to boost the development of the national floriculture industry and to exploit the unique features of Chilean species. One of the most important outcomes of these breeding projects was the development of the first intergeneric hybrid, Chlorogavilea 'Máxima' obtained from Chloraea crispa Lindl., and Gavilea longibracteata (Lindl.) Sparre ex Navas (Orchidaceae, Chloraeinae). The main objective of this work is to present the characteristics of this new hybrid, including its floral display, size, and its potential use as an ornamental pot plant.

\section{Origin}

Chloraea crispa and G. longibracteata are geophytic orchids widely distributed in Chilean forests. Chloraea crispa from $\approx 38^{\circ} \mathrm{S}$ to $41^{\circ} \mathrm{S}$ and $G$. longibracteata from $\approx 30^{\circ} \mathrm{S}$ to $41^{\circ} \mathrm{S}$ (Humaña et al., 2008; Valdivia et al., 2010). Both species exhibit pauciflorous inflorescences with conspicuous white-colored flowers, with $G$. longibracteata having a small sized, yellow-colored labellum. The species are self-compatible, with flowering and fruiting occurring during the southern hemisphere spring season from October to January in C. crispa, and from September to November in G. longibracteata (Humaña et al., 2008; Valdivia et al., 2010). Chloraea crispa has distinctive traits that were desirable to incorporate into $G$. longibracteata, such as large flowers, floral display, color, and shape.

In 2005, a bigeneric hand-cross from $C$. crispa (Q173) and $G$. longibracteata (G1) was obtained and designated as Chlorogavilea 'Máxima' (C17-05) (Fig. 1). The name of the cultivar was recorded at the Royal Horticultural Society which is the International Cultivar Registration Authority for orchid hybrids, under the name of Chlorogavilea 'Máxima' (P. 25121). The parental species were cultivated in an unheated greenhouse at the Faculty of Agronomy of the Pontificia Universidad Católica de Valparaíso, Quillota, Región of Valparaíso, Chile $\left(32^{\circ} 52^{\prime} \mathrm{S}, 71^{\circ} 14^{\prime} \mathrm{W}\right)$. The climate of Quillota is characterized by cool winters (average temperatures in July of 5.5 to $16.8{ }^{\circ} \mathrm{C}$ ), hot dry summers (average temperatures in January of 11.5 to $26.8{ }^{\circ} \mathrm{C}$ ), and an average precipitation of $436.4 \mathrm{~mm}$ (Novoa et al., 1989).

Chlorogavilea 'Máxima' was developed from crossings between $C$. crispa and $G$. longibracteata. The flowers were emasculated, hand-cross pollinated with parental pollen, and bagged until fruit formation. The seeds were collected before the dehiscence of the fruit, dried at room temperature, and placed into glass tubes stored at $5-6{ }^{\circ} \mathrm{C}$ until they were sown. The seedlings were obtained under in vitro conditions through symbiotic germination in which the seeds were germinated together with mycorrhizal fungus from the genera $R h i$ zoctonia, which was isolated from the roots of C. crispa (Verdugo et al., 2007). Subsequently, they were transplanted when they reached three to four leaves in an unheated greenhouse (as mentioned above). The plants were grown in $4-\mathrm{L}$ pots filled

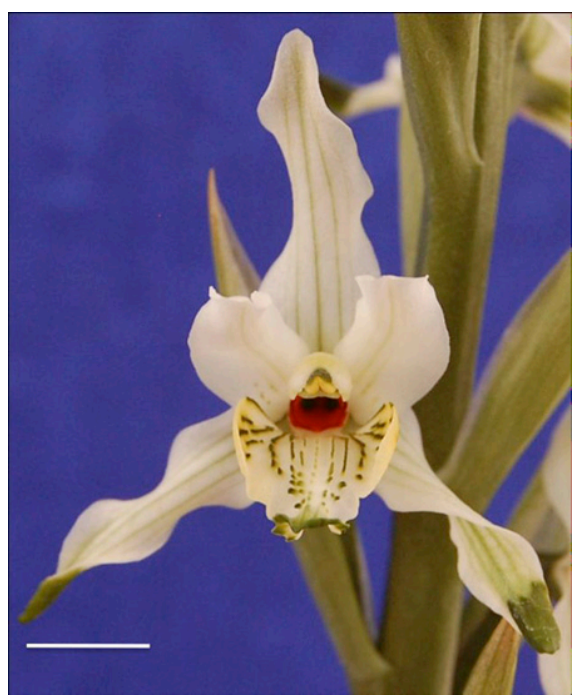

Fig. 1. Chlorogavilea 'Máxima' flower. Bar $=1 \mathrm{~cm}$. 
Table 1. Floral comparative traits of the hybrid with their parents.

\begin{tabular}{llll}
\hline Traits & \multicolumn{1}{c}{ Chloraea crispa } & Gavilea longribracteata & Chlorogavilea 'Máxima' \\
\hline Number of flower stalks & 1 & $1-3$ & $1-3$ \\
Number of flowers per inflorescence & $10-20$ & $10-40$ & $30-32$ \\
Length of flower stalk & $40-95 \mathrm{~cm}$ & $35-60 \mathrm{~cm}$ & $70-75 \mathrm{~cm}$ \\
Length of inflorescence & $10-50 \mathrm{~cm}$ & $10-30 \mathrm{~cm}$ & $50-56 \mathrm{~cm}$ \\
Length of dorsal sepal & $25-35 \mathrm{~mm}$ & $9-12.5 \mathrm{~mm}$ & $20-22 \mathrm{~mm}$ \\
Length of lateral sepal & $2.2-3.3 \mathrm{~cm}$ & $1.6-2 \mathrm{~cm}$ & $2.4-3 \mathrm{~cm}$ \\
Lateral sepals with fleshy apex & No & Yes & Yes \\
Length of lip & $4-4.5 \mathrm{~cm}$ & $0.75-0.9 \mathrm{~cm}$ & $2.4-3 \mathrm{~cm}$ \\
Lip shape & Suborbicularis to slightly trilobate & Deeply trilobate & Trilobate \\
Sepal color & White & Pale yellow & Pale yellow \\
Petal color & White & Pale yellow with green apex & Pale yellow with green apex \\
Lip color & White & Yellow with green edges & Yellow with green apex \\
Column & Elongated, striped orange red & Short, white with swollen & Shortly elongated, striped \\
& with nectariferous channels & nectaries & orange with nectariferous \\
& & & channels \\
\hline
\end{tabular}

with a mixture of disinfected sand and organic compost $(1: 1)$ for 5 years until they reached the flowering stage. The plants were watered twice a week during the period of vegetative growth and were fertilized and treated against diseases as required.

\section{Description}

Chlorogavilea 'Máxima' is an herbaceous terrestrial plant, with fasciculated and cylindrical roots. The leaves are arranged in a basal rosette of lanceolate lamina with reticulate veins. The racemose inflorescence with 30 to 32 flowers is covered by several sheathing, which are similar to the basal leaves; the floral bracts are lanceolate and acute, longer than the flowers at the base of the inflorescence. The flowers are pale yellow, odorless, and characterized by a median size between both parentals. The dorsal sepals are similar in length to the lateral sepals both are lanceolate and obtuse with five longitudinal veins. The lateral sepals possess a fleshy colored apex. The petals are asymmetrical, ovate, with three to five longitudinal veins, and sometimes with wart-like outgrowths on the lower half of the veins. The lip is trilobate in which the lateral lobes are rounded and have wart-like outgrowths; the central lobe is oblongo-lanceolate with crests and an acute, fleshy, and greenish apex. The column is shortly elongated, with orange stripes and nectariferous channels. The ovary is unilocular and the capsule has not been described.

\section{Outstanding Features and Potential Use}

The hybrid shows characteristics of both parents, as well as a number of intermediate traits (Table 1). The hybrid resembles G. longibracteata in several ways, such as the floral display and the color and shape of flowers. Nevertheless, the most notable features are the size of its flowers, larger than G. longibracteata (Table 1). A trilobate lip is an intermediate trait between both parents, whereas the shortly elongated column with orange stripes and a yellow throat with orange edges (nectariferous channels) are similar to C. crispa. The flowering occurs between October to November and the flowering time from the first to the last flowers is around 1 month. This hybrid might be suitable for use as an ornamental pot plant and for cultivation in temperate climate conditions. No growth regulators should be required for its use as a pot plant.

\section{Availability}

Like many other hybrids obtained in this breeding program, Chlorogavilea 'Máxima' has not been patented. The in vitro propagation has some degree of difficulty, which has not allowed the commercial sale of the hybrid. Further studies are required for the optimization of the clonal propagation protocol.

\section{Literature Cited}

Bridgen, M.P., E. Olate, and F. Schiappacasse. 2002. Flowering geophytes from Chile. Acta Hort. 570:75-80.
Cisternas, M.A., G.A. Salazar, G.S. Verdugo, P. Novoa, X. Calderon, and M. Negritto. 2012. Phylogenetic analysis of Chloraeinae (Orchidaceae) based on plastid and nuclear DNA sequences. Bot. J. Linn. Soc. 168:258-277.

De, L.C. and R.P. Medhi. 2015. Orchid: A diversified component of farming systems for profitability and livelihood security of small and marginal farmers. J. Global Biosciences 4:1393-1406.

Higgins, W. and P. Alrich. 2013. George Hansen \& the hybrid list. Orchid Digest 77:131-134.

Humaña, A.M., M.A. Cisternas, and C.E. Valdivia. 2008. Breeding system and pollination of selected orchids of the genus Chloraea from central Chile. Flora 203:469-473.

Novoa, P., J. Espejo, M.A. Cisternas, M. Rubio, and E. Domínguez. 2006. Guía de campo de las orquídeas chilenas (ed.). Corporación Chilena de la Madera, Concepción, Chile.

Novoa, R., S. Villaseca, P. Del Canto, J. Rouanet, C. Sierra, and A. Del Pozo (eds.). 1989. Mapa agro-climático de Chile. Santiago.

ODEPA, Oficina de estudios y políticas agrarias. 2015. Productos exportados Mundo, enero a diciembre 2014. 11 May 2015. < http://www.odepa.cl/ series-anuales-por-producto-de-exportacionesimportaciones/>.

Steinfort, U., M.A. Cisternas, R. García, H. Vogel, and G.S. Verdugo. 2012. Phenological cycle and floral development of Chloraea crispa (Orchidaceae). Cien. Inv. Agr. 39:377-385.

Valdivia, C.E., M.A. Cisternas, and G.S. Verdugo 2010. Reproductive biology aspects of two species of the genus Gavilea (Orchidaceae, Chloraeinae) in populations from central Chile. Gayana Bot. 67:44-51.

Verdugo, G., J. Marchant, M.A. Cisternas, X. Calderón, and P. Peñaloza. 2007. Caracterización morfométrica de la germinación de Chloraea crispa Lindl. (Orchidaceae) usando análisis de imagen. Gayana Bot 64:232-238. 